Kościót Chrystusowy, red. T. Dzidek, Ł. Kamykowski, A. Napiórkowski,

Kraków 2019, s. 59-71 (Teologia Fundamentalna, 4)

DOI: http://dx.doi.org/10.15633/9788374388368.04

\title{
III. Rozwój eklezjologii katolickiej
}

o. Andrzej Napiórkowski OSPPE

Aby dotrzeć do aktualnego rozumienia Kościoła i właściwie je przyswoić, należy odwołać się do przewodnich koncepcji eklezjologii katolickiej. Dlatego przedstawimy teraz zasadnicze rozumienia Kościoła, jakie on sam o sobie wypracowywał i przedkładał przez wieki.

\section{A. Charyzmatyczna wspólnota pierwszych wieków}

Pierwsi naśladowcy Jezusa Chrystusa nade wszystko praktycznie urzeczywistniali Jego misyjny nakaz:

Idźcie na cały świat i głoście Ewangelię wszelkiemu stworzeniu! Kto uwierzy i przyjmie chrzest, będzie zbawiony; a kto nie uwierzy, będzie potępiony (Mk 16, 15-16).

Wraz uzyskaniem wolności (edykt mediolański 313 r.) treści wiary próbowano artykułować na synodach i soborach, w dysputach i na liturgii, w apologiach, w świadectwie codziennego życia, posuniętym aż do męczeństwa czy życia pustelniczego w cenobiach bądź eremach. Wierni żyli rzeczywistością Jezusowego Kościoła, jego naturą i posłannictwem, nie pytając o ich teologiczne znaczenie.

Teologia przyjmowała postać komentarzy do poszczególnych ksiąg Pisma Świętego, gdzie podkreślano wszczepienie Kościoła w Chrystusa oraz Jego immanencję w Kościele. Patrystyka nawiązywała zatem do biblijnych obrazów i figur. Wśród nich często pojawiało się określenie „Kościól-Matka”, które stanowi parafrazę Tertuliana (160-220) słów św. Jana apostoła: „do wybranej Pani i do jej dzieci” (2 J 1, 1). Natomiast przedstawiając naturę i misję Kościoła, sięgano do niebiblijnych obrazów, jak np. do metafory księżyca. Wiele wątków eklezjologicznych 
odnajdujemy w rozprawie De civitate Dei Agustyna z Hippony (†430), który ukazuje porządek doczesny i wieczny ${ }^{1}$.

\section{B. Powstanie państwa kościelnego w VIII w.}

Myśl o Kościele została mocno naznaczona erygowaniem państwa kościelnego (755 r.), rządzonego przez papieży jako świeckich monarchów. Wspólnota wierzacych nabrała charakteru instytucjonalnego. Jak w patrystyce, tak i teraz Kościół nie stanowił przedmiotu teologicznych kontrowersji. Stawał się on zbawczą instytucją, mającą swój monarchiczny ustrój, ześrodkowany na papieżu jako najwyższym władcy. Przynależność do Kościoła była czymś oczywistym, wręcz naturalnym, wyznaczała tożsamość religijną oraz określała codzienne życie.

W świadomości wiernych wczesnego średniowiecza na pierwszy plan zaczął wybijać się aspekt Kościoła zewnętrznego, instytucjonalnego i prawnego. Eklezjologią zajmowali się przede wszystkim kanoniści. Stąd na Zachodzie dominowało myślenie o Kościele w kategoriach jurydycznych, a na Wschodzie w kategoriach mistycznych. Wzmacniające się różnice liturgiczne, doktrynalne oraz kulturowe i polityczne między Rzymem a Bizancjum doprowadziły ostatecznie w 1054 r. do rozpadu Kościoła na wschodni i zachodni, co spotęgowało refleksję na temat jego jedności.

\section{Rozkwit instyłucjonalnego ujęcia Kościoła średniowiecza}

W rozwoju eklezjologii średniowiecznej wyróżnia się cztery etapy: epokę karolińską (VIII-X w.), reformę gregoriańską (XI-XII w.), złotą scholastykę (XIII w.) i schyłek średniowiecza (XIV-XV w.). W ciągu tych ośmiu wieków rozwijały się dwa rodzaje eklezjologii z czasem coraz bardziej odmienne od siebie. Pierwszy rodzaj, uprawiany w środowisku mniszym i uniwersyteckim, podkreślał życie wewnętrzne Kościoła, opierając się na idei Ciała Chrystusa. Drugi rodzaj prezentowali kanoniści, którzy postrzegali Kościół jako instytucję, skupiając się na kwestii władzy kościelnej i prymacie papieskim².

1 Por. A. Napiórkowski, Bosko-ludzka wspólnota. Podstawy katolickiej eklezjologii integralnej, Kraków 2010, s. 153-204.

2 Por. A. Czaja, Traktat o Kościele. Dogmatyka, t. 2, Warszawa 2006, s. 318-319. 
Epoka karolińska pogłębiła przepaść między duchowieństwem a laikatem. Trzeba tu dodać, iż zakonników zaliczano do świeckich. W systemie feudalnej struktury doszło do utożsamienia władzy kościelnej i doczesnej. Wykazywano wyższość Stolicy Apostolskiej w odniesieniu do innych siedzib biskupich oraz jej wiodącą rolę w całym Kościele powszechnym. W środowisku zakonnym uwagę zwrócono na znaczenie Eucharystii dla wewnętrznego życia Kościoła. Doszło nawet do zmiany w nazewnictwie, gdyż w kręgach Rabana Maura (†856) Kościół zaczęto nazywać Ciałem mistycznym (corpus mysticum), a Ciało Pańskie w Eucharystii - Ciałem prawdziwym (corpus verum) ${ }^{3}$.

Z kolei tzw. reforma gregoriańska, powiązana przede wszystkim z papieżem Grzegorzem VII (1073-1085), posłużyła dalszemu umocnieniu pozycji papiestwa. Dążąc do uwolnienia Kościoła od wpływów władzy świeckiej, papież pragnął go tym samym uwolnić od symonii, nikolaizmu i innych nadużyć. Dokument Dictatus papae (1075) ukazywał papieża jako jedyne źródło i normę prawa, najwyższego i powszechnego sędziego. Konkordat w Wormacji (1122 r.) oraz IV Sobór Laterański potwierdziły wyjątkową pozycję biskupa Rzymu jako ostatecznego kryterium kościelności. Z jednej strony reforma gregoriańska przyniosła wzmocnienie Kościoła na zewnątrz, a z drugiej - spowodowała jego wewnętrzne osłabienie przez zniszczenie kolegialności i niedowartościowanie duchowości ${ }^{4}$.

Trzeci etap średniowiecza tworzyła tzw. złota scholastyka. Mimo iż w XII i XIII wieku pojawili się tacy teologiczni geniusze, jak Aleksander z Hales, Albert Wielki, Tomasz z Akwinu, Bonawentura czy Jan Duns Szkot, to spod ich pióra nie wyszedł żaden traktat na temat Kościoła. W Kościele wciąż widziano bardziej stronę ludzką, niż boską. Miały na to wpływ nie tylko myślowe kategorie arystotelizmu i platonizmu, lecz również Sentencje Piotra Lombarda (†1160), wyznaczające kierunki uprawiania teologii na wiele wieków. Dzieło Lombarda eliminowało eklezjalne kwestie z badań teologicznych.

Brak traktatu o Kościele pierwszych trzynastu wieków sprzyjał jego instytucjonalnemu zawężeniu, jakkolwiek pojawiały się wskazania na związek Kościoła z Chrystusem, np. Tomasz z Akwinu pisał o Kościele jako instytucji, czyli formie istnienia Ciała Mistycznego i nowego życia w Chrystusie. Akwinata postrzegał też Kościól jako sakrament i misję, czyli narzędzie urealniania Mistycznego Ciała. Tylko nieliczni, np. Piotr Damiani, pisali o życiodajnym działaniu Ducha Świętego w Chrystusowym Ciele 5 .

3 Por. E. Ozorowski, Kościót. Zarys eklezjologii katolickiej, Wrocław 1984, s. 230 n.

${ }^{4}$ Por. A. Czaja, Traktat o Kościele, dz. cyt., s. 320-321.

5 Por. Y. Congar, L'idée chez saint Thomas d'Aquin de l'Eglise, [w:] tenże, Esquisses du mystère de l'Eglise, Paris ${ }^{2} 1953$, s. 59-91; T. Dzidek, Mistrzowie teologii. Prezentacja - antologia tekstów - dyskusja, Kraków 1998, s. 325-329. 
Akcentowanie widzialności Kościoła objawiało się też jego pojmowaniem jako walczącego. Angielski biskup z Hereford, Robert Melun (1100-1167), określił Kościól jako walczący (Ecclesia militans), cierpiący (patiens) oraz tryumfujący (triumphans). Przejawem takiego myślenia były wyprawy krzyżowe. Imperializm Kościoła wyrażał się we władzy papieża również nad wyznawcami innych religii, poganami oraz niewierzącymi.

Ostatni etap średniowiecza, obejmujący wieki XIV i XV, określany jest jako jego schyłek. Ten czas znaczy także tzw. schizma zachodnioeuropejska (13781417), kiedy to doszło - wskutek podziałów wśród duchowieństwa - do gorszącego zjawiska, jakim było urzędowanie dwóch (a niekiedy nawet trzech) papieży. Jeden $z$ nich przebywał w Rzymie, a drugi w Awinionie we Francji. Ich wzajemna wrogość i konkurencja miały niewiele wspólnego z Ewangelią Jezusa. W zasadzie jest to dalsze wzmocnienie eklezjologii instytucjonalnej, uwypuklającej widzialność Kościoła z jego strukturą hierarchiczną. Kościół pojmowano jako królestwo z najwyższą władzą papieża. W takim klimacie powstały pierwsze traktaty eklezjologiczne. De regimine christiano (1301/1302) Jakuba z Viterbo ukazuje wyższość papieża Bonifacego VIII (1294-1303) nad królem francuskim Filipem Pięknym ${ }^{6}$. Przeciwwagą staje się idea koncyliaryzmu, głosząca wyższość soboru nad papieżem, którą z kolei odrzuca najgłośniejszy ówczesny traktat, Summa de Ecclesia (ok. 1453 r.) Juana Torquemady $(\dagger 1468)^{7}$.

Kwestionowanie absolutyzmu papieskiego tak przez bogomiłów, katarów i albigensów, wzywających do sprzeciwu wobec kleru, jak i przez tezy Marsyliusza z Padwy i Wilhelma Ockhama, głoszących supremację państwa nad Kościołem, stanowiło również znaczące impulsy dla kanonistów i teologów (Mikołaj z Kuzy, †1464) do podjęcia głębszej refleksji nad tajemnicą Kościoła ${ }^{8}$.

\section{Niewidzialna wspólnota w postulatach reformacji}

Nasilające się głosy i postawy wzywające do zmian w Kościele, wyzwoliły ostatecznie potężny ruch odnowy. Tacy katoliccy reformatorzy jak Jan Wiklef (†1385),

${ }^{6}$ Por. D. Trapp, Jakub von Viterbo, [w:] Lexikon für Theologie und Kirche, t. 5, Freiburg-BaselRom-Wien 1960, k. 849.

${ }^{7}$ Zob. K. Binder, Wesen und Eigenschaften der Kirche bei Kardinal Juan de Torquemada, Innsbruck 1955.

${ }^{8}$ Por. A. Napiórkowski, Bosko-ludzka wspólnota. Podstawy katolickiej eklezjologii integralnej, Kraków 2010, s. 181-185. 
Jan Hus ( $† 1415)$, Huldrich Zwingli (†1531), Marcin Luter (†1546), Filip Melanchton $(\dagger 1560)$, Jan Kalwin $(\dagger 1564)$ i wielu innych opowiedzieli się za radykalnymi zmianami w łonie papiestwa, pierwotnie nie pragnąc ustanawiania innego Kościoła. Wprowadzając podział na Kościół niewidzialny i widzialny, głosili oni Kościół ukryty (niewidzialny/zgromadzenie wybranych). Jest on zgromadzeniem wierzących, a nie widzialną instytucją. Na ziemi znany jest tylko Bogu. Wierni podlegają tylko Jemu oraz Jego słowu. Natomiast istniejące kościelne struktury organizacyjno-prawne są ludzkim wymysłem i nie pochodzą od Chrystusa, dlatego trzeba od nich odejść.

Według reformatorów prawdziwy Kościół rodzi się ze Słowa i Ducha Bożego, stąd też jest on creatura verbi: dzięki Słowu się gromadzi, jest podtrzymywany i budowany. W ten sposób jest on „świętym chrześcijańskim ludem Bożym w Słowie" (das heilige christliche Volk Gottes im Wort). Dlatego reformatorzy uważali, iż sakramentalna struktura, narzucona przez rzymskich papieży, jest ideologicznym uzasadnieniem klerykalnego systemu władzy, która odmawia bezpośredniego dostępu chrześcijanom do zbawienia9.

\section{E. Sobór Trydencki: „społeczność doskonała”}

Ostatecznie doszło do tragedii, jaką był podział Kościoła. Z protestantyzmu wyłoniło się wiele kościelnych wspólnot, które stanęły w opozycji do Kościoła rzymskiego. Ten dramatyczny stan spraw wymusił na papiestwie podjęcie dzieła reformy. Doszło do zwołania Soboru Trydenckiego (1545-1563), który wprawdzie nie podjął wprost problematyki eklezjalnej, lecz wypracował szereg znaczących dekretów regulujących kościelne życie, doktrynę i moralność. Stało się to możliwe dzięki ogromnej pracy i poświęceniu szeregu wybitnych papieży, świętych, teologów, założycieli i fundatorów nowych zgromadzeń i wspólnot, którzy przyczynili się nie tylko do kształtowania soborowej nauki, lecz również do wcielenia jej w życie. Wśród ludzi światłych i ożywionych duchem Bożym można wymienić św. kard. Karola Boromeusza (1538-1584), papieża Piusa IV (1499-1565), kard. Stanisława Hozjusza (1504-1579) czy św. kard. Roberta Bellarmina (1542-1621).

W wirze polemik z reformatorami skupiono się na tym, co oni kwestionowali. Stąd odrzucenie przez nich wymiaru widzialnego, który wiązał się z hierarchicz-

9 Por. P. Jaskóła, Reformatorskie postulatyJ. Husa, w: Reformatorzy a Kościót rzymski, red. A. Napiórkowski, Kraków 2017, s. 9-33; A. Nadbrzeżny, Kościót święty i grzeszny. Eklezjologia M. Lutra, w: tamże, s. 35-60; I. Bokwa, Kalwińska wizja Kościota, w: tamże, s. 61-90 ; P. Kopiec, F. Melanchtona wizja reformacji, w: tamże, s. 209-235. 
nością i sakramentalnością Kościoła, spowodowało zaakcentowanie kościelnej doczesności i widzialności. Aspekt wewnętrzny, duchowy, nadprzyrodzony zepchnięto na drugi plan. Swe sformułowanie eklezjologia potrydencka znalazła w dziele De controversiis (1586-1593) św. Roberta Bellarmina ${ }^{10}$. Pisał on, że istnieją nie dwa Kościoły, ale jeden i gromadzi on wierzących - pod kierownictwem prawomocnych pasterzy, a zwłaszcza jedynego na ziemi zastępcy Chrystusa, biskupa rzymskiego - dla wyznawania tej samej wiary chrześcijańskiej i wspólnoty tych samych sakramentów. Bellarminowska definicja ujmowała Kościół jako widzialne społeczeństwo, jak np. zgromadzenie ludu rzymskiego, królestwo Francji czy Republika Wenecka. Teologowie rzymscy chcieli ujmować Kościół jako doskonałą społeczność (societas perfecta), która wymaga nawrócenia człowieka, ale nie zmian instytucjonalnych.

Warto zauważyć, iż wielkie debaty na temat ustroju Kościoła doprowadziły do wypracowania nauki o tzw. znamionach Kościoła katolickiego ${ }^{11}$. Niestety teologowie zajmowali się w niej prawie wyłącznie widzialną stroną znamion Kościoła (jedność, świętość, powszechność i apostolskość), zamierzonych i chcianych przez Chrystusa, dzięki którym wyróżnia się on wśród Kościołów schizmatyckich i wspólnot protestanckich oraz dowodzi swojej prawdziwości.

\section{F. Oświeceniowe herezje}

Rozumienie Kościoła podane przez Bellarmina miało na celu podkreślenie różnicy od wizji reformatorów. Włoski jezuita pisał też o Kościele jako żywym ciele, który posiada duszę, czyli wewnętrzne dary Ducha Świętego: wiarę, nadzieję i miłość, jakie łączą wierzących z Chrystusem Głową, stanowiąc jednocześnie widzialną społeczność. Niestety ta minimalistyczna wizja z jego $D e$ controversiis weszła na stałe do nauki o Kościele i zapanowała w następnych wiekach. To instytucjonalne ujęcie, jakie osłabiało rozumienie misterium Kościoła, dodatkowo wzmagały prądy oświeceniowe. Rozwijający się deizm, negowanie religii, ograniczanie Kościoła do funkcji wychowawczej (corpus morale) i użytecznej dla społeczeństwa (caritas), liberalne tezy teologii protestanckiej, kasaty zakonów kontemplacyjnych prowadziły do zawężonego przekonania, iż Kościól to kler, a laicy mają wspierać jego działania. Sami też teologowie akcentowali

10 Por. W. Łydka, Bellarminorwska definicja Kościota i jej wptyw na późniejszą teologię katolicka, [w:] „Roczniki Teologiczno-Kanoniczne” 13/2 (1966), s. 57-75.

11 Por. S. Nagy, Via notarum we wspótczesnej eklezjologii apologetycznej, [w:] „Roczniki Teologiczno-Kanoniczne” 15/2 (1968), s. 93-115. 
rozróżnienie między Kościołem nauczającym i słuchającym, wskutek czego świeccy stali się pasywnym przedmiotem aktywnej działalności hierarchii.

W takim klimacie w XVII i XVIII wieku wyrosły nurty gallikanizmu, febronianizmu oraz józefinizmu, godząc w autonomiczność i nadprzyrodzoność Kościoła ${ }^{12}$. Władcy oświeceniowi, dążąc do podporządkowania Kościoła swoim interesom, podejmowali starania ograniczenia prerogatyw biskupa Rzymu. Zwolennicy gallikanizmu uważali, iż zasady doktrynalno-prawne Kościoła we Francji mają być określane bez łączności ze Stolicą Apostolską ${ }^{13}$. Natomiast przedstawiciele febronianizmu głosili wyższość episkopatów nad zwierzchnictwem papieża, dopuszczając mianowanie biskupów przez władcę, a nie papieża. Odmianą febronianizmu w monarchii austro-węgierskiej był józefinizm, ingerujący w administrację Kościoła i jego życie wewnętrzne.

\section{G. Odrodzenie nauki o Kościele w XIX i XX w.}

Zwieńczeniem eklezjologii instytucjonalnej była konstytucja Soboru Watykańskiego I Pastor aeternus (1870 r.), poświęcona w całości pasterskiemu i nauczycielskiemu urzędowi biskupa rzymskiego. Dokument zdefiniował papieski prymat jurysdykcyjny oraz jego nieomylność, co miało służyć umocnieniu władzy papieża, który utracił władzę świecką. Niestety ta problematyka początkowo zyskała najwięcej uwagi w teologicznych rozprawach między I oraz II Soborem Watykańskim. Jednak kościelne zmiany pastoralne i prawne oraz polityczne i społeczne zmusiły do zajęcia się bardziej istotnymi aspektami życia wierzących.

Właściwa odnowa eklezjologii katolickiej rozpoczęła się w XIX w. w Tybindze. Tworzyli ją J. S. Drey (†1853), P. A. Gratz (†1849), J. B. Hirscher (†1865) oraz J. A. Möhler (1796-1838 ${ }^{14}$. Kontynuowała ją następnie szkoła rzymska (Collegium Romanum), reprezentowana przez takich teologów, jak: J. Perrone $(† 1876)$, C. Passaglia $(† 1887)$, K. Schrader $(\dagger 1875)$, J. B. Franzelin $(† 1886)$, J. Kleutgen $(† 1883)$ oraz J. M. Scheeben $(† 1888)$. Najwybitniejszy przedstawiciel

12 Por. A. Napiórkowski, Herezje, [w:] LTF, s. 456-462.

${ }^{13} \mathrm{~W} 1853 \mathrm{r}$. francuscy biskupi zebrani w Amiens potępili gallikanizm jako niezgodny z katolicką doktryną i uwłaczający godności Stolicy Apostolskiej. Po ogłoszeniu dogmatu o papieskiej nieomylności na Soborze Watykańskim I (1870) i po przeprowadzeniu rozdziału Kościoła od francuskiego państwa (1905), gallikanizm nie odgrywał już większej roli w tym kraju.

14 Por. J. R. Geiselmann, Die katholische Tübinger Schule. Ihre Eigenart, Freiburg i. Breisgau, 1964; W. Kasper, Johann Adam Möhler - Wegbereiter des modernen Katholizismus, [w:] „Internationale katholische Zeitschrift Communio"17 (1988), s. 433-443. 
szkoły w Tybindze, J. A. Möhler, postulował powrót do historii i tradycji patrystycznej. Swoją dojrzałą myśl o Kościele wyraził on w Symbolice ${ }^{15}$. Bazując na unii hipostatycznej w Chrystusie, ukazał Kościól jako połączenie natur boskiej i ludzkiej, jednakże różniących się wzajemnie. Widzialny Kościół ziemski jest nieustannie odnawiającym się Synem Bożym, czyli trwałym Wcieleniem. Mimo że tworzą go ludzie, to nie jest on wyłącznie ludzki: jest równocześnie boski i ludzki, stanowi jedność obu elementów ${ }^{16}$. Eklezjologia Möhlera nie tylko dała początek odrodzeniu teologii Kościoła w XIX w., lecz jest aktualna również dzisiaj.

W podobnym kierunku poszła szkoła rzymska, ukazując naturę boską i ludzką Kościoła. Jej idee eklezjologiczne znalazły swój wyraz nie tylko w pracach jej przedstawicieli, lecz w przygotowanym przez nich schemacie De ecclesia I Soboru Watykańskiego. Niestety ta konstytucja nie została uchwalona (mimo że mogła oznaczać zakończenie eklezjologii instytucjonalnej), gdyż obrady przerwano z powodu wojny francusko-pruskiej. Koniec tej wizji Kościoła należy zatem wiązać z rozwiązaniem Państwa Kościelnego, co miało miejsce w 1870 r. Stosunki między papiestwem a rządem włoskim ostatecznie uregulowały tzw. traktaty laterańskie w r. 1929, kiedy Włochy uznały suwerenną władzę papieży w Watykanie i podpisano konkordat ${ }^{17}$.

Właściwy rozkwit odrodzenia eklezjologicznego przypada jednak dopiero na XX w., na okres między dwiema wojnami światowymi (1918-1939). R. Guardini (†1968) wygłosił proroctwo: „Jesteśmy świadkami procesu o nie dającym się przewidzieć znaczeniu: Kościół rozpoczyna się budzić w dusza$\mathrm{ch}^{18}$, a protestant O. Dibelius ( $\left.† 1967\right)$ proklamował nadchodzący czas wiekiem Kościoła ${ }^{19}$. W Kościele zaczęto coraz wyraźniej uwypuklać obok elementu ludzkiego, społeczeństwa doskonałego (societas perfecta), również pierwiastek boski (charyzmaty i łaskę), a więc wspólnotę nadprzyrodzoną. Wyraźnie dojdzie to do głosu w encyklice O Mistycznym Ciele Chrystusa (Mystici Corporis Christi) Piusa XII, który napisze, iż duszą Ciała Mistycznego jest Duch Swięty²0.

Dla generacji 1920-1940, jak zauważa G. Thils, hasło „Ciało Mistyczne” reprezentowało pełnię wartości religijnych i apostolskich: unię Chrystusa z Kościołem, jej charakter witalny, łączność aspektu niewidzialno-nadprzyrodzonego

15 Zob. J. R. Geiselmann, J. A. Möhler: Symbolik oder Darstellung der dogmatischen Gegensätze der Katholiken und Protestanten nach ibren öffentlichen Bekenntnischriften, t. 1, Köln 1960; t. 2, Köln, 1961.

16 Por. J. A. Möhler, Symbolik, t. 1, dz. cyt., s. 389; T. Dzidek, Mistrzowie teologii. Prezentacjaantologia tekstów - dyskusja, Kraków 1998, s. 477-483.

17 Por. Z. Zieliński, Watykański Sobór I, w: EK, t. 20, k. 277-280.

18 Tenże, Vom Sinn der Kirche, Mainz 1922, s. 1.

19 Por. O. Dibelius, Das Jabrhundert der Kirche, Berlin 1926.

20 Por. AAS 35 (1943), s. 193-248; DS 3800-3822. 
z aspektem widzialno-zewnętrznym, dowartościowanie wszystkich członków tego ciała, a więc hierarchii i wiernych oraz współpracę między nimi w kontynuacji dzieła zbawczego ${ }^{21}$. Wśród obfitej literatury teologicznej o Kościele - mistycznym Ciele Chrystusa na szczególną uwagę zasługują: dwutomowa monografia E. Merscha (†1944), zawierająca omówienie nauki w całej tradycji doktrynalno-historycznej, począwszy od Biblii, poprzez teologię zarówno grecką, jak i zachodnią, aż do czasów jemu współczesnych. Pewną rolę odegrała też monografia S. Trompa, ponieważ jej idee były bliskie encyklice Mystici Corporis Piusa XII ${ }^{22}$. Prezentując alegorię mistycznego Ciała Chrystusa, jezuita Tromp postawił tezę, że dla wiernych stanowi je właśnie Kościół rzymskokatolicki.

Odrodzenie w nauce o Kościele wiązało się też ze studiami na temat ludu Bożego (D. Koster, L. Cerfaux), kwestią Żydów w dziejach zbawienia (Ch. Journet), sakramentalnym charakterem Kościoła (O. Semmelroth, K. Rahner. Ch. Moeller, E. H. Schillebeeckx), przynależnością innych wyznań chrześcijańskich do Kościoła, rolą świeckich i ich kapłaństwem (G. Philips, Y. Congar), problematyką misyjną i ewangelizacją świata, relacją Kościoła do współczesności (P. Teilhard de Chardin, K. Wojtyła), dramatem humanizmu ateistycznego (H. de Lubac) ${ }^{23}$.

\section{H. Misterium Kościoła: Drugi Sobór Watykański}

Obrady Drugiego Soboru Watykańskiego (1962-1965) miały zatem swoje oparcie nie tylko w Biblii, nauce Ojców i liturgii, lecz w licznych i poważnych studiach eklezjologicznych. Można było tworzyć nowe rozumienie Kościoła, czemu Sobór dał wyraz zwłaszcza w dwóch konstytucjach: dogmatycznej Lumen gentium oraz duszpasterskiej w świecie współczesnym Gaudium et spes ${ }^{24}$. Sobór promulgował ostatecznie szesnaście dokumentów: 4 konstytucje, 9 dekretów i 3 deklaracje. Dla nowej eklezjologii ważne są też dekrety: o Kościołach wschodnich katolickich Orientalium Ecclesiarum, o ekumenizmie Unitatis redintegratio, o pasterskich zadaniach biskupów w Kościele Christus Dominus, o przystosowanej odnowie życia zakonnego Perfectae caritatis, o formacji kapłańskiej Optatam totius, o apostolstwie świeckich Apostolicam actuositatem, o działalności misyjnej Kościoła

${ }^{21}$ Por. G. Thils, Orientations de la théologie, Louvain 1958, s. 94-95.

22 Por. S. Tromp, Corpus Christi quod est Ecclesia. t. 1: Introductio generalis, Romae 1937.

${ }^{23}$ Por. J. Sieg, Refleksja Soboru nad obecnościa Kościota w świecie wspótczesnym, w: H. Bogacki, S. Moysa (red.), Kościót w świetle Soboru, Poznań 1968, s. 513-514.

${ }^{24}$ Por. A. Kubiś, Wprowadzenie do Lumen gentium - Konstytucji dogmatycznej o Kościele [w:] Idee przewodnie Konstytucji soborowej o Kościele, Kraków 1971, s. 28-44; tenże, Vaticanum II - wydarzenie i dzieto, „Analecta Cracoviensia” 29 (1987), s. 459-470. 
Ad Gentes, o posłudze i życiu kapłanów Presbyterorum ordinis. Z kolei odnowioną eklezjologię wniosły następujące deklaracje: o stosunku Kościoła do religii niechrześcijańskich Nostra aetate oraz o wolności religijnej Dignitatis humanae.

Soborowa doktryna ujmuje Kościół integralnie, łącząc w nim to, co transcendentne, boskie, niewyrażalne, niewidzialne, wieczne, nadprzyrodzone, święte i niebiańskie z tym, co immanentne, ludzkie, określone, widzialne, czasowe, naturalne, grzeszne i ziemskie. Dokonała się „rewolucja kopernikańska” w pojmowaniu tajemnicy Kościoła. Vaticanum II przeszedł do historii jako sobór eklezjologiczny, gdyż w swoich dwóch wiodących konstytucjach, Lumen gentium i Gaudium et spes, ukazał Kościół od wewnątrz (Ecclesia ad intra) oraz od zewnątrz (Ecclesia ad extra).

W konstytucji Lumen gentium akcent położony został na naturze i powszechnym posłannictwie Kościoła pochodzącym od Boga przez Chrystusa w Duchu Świętym. Kościołem są wszyscy wierni ochrzczeni. Dokument - będący dojrzałą syntezą eklezjologii katolickiej - tworzy 8 rozdziałów: I. Misterium Kościoła; II. Lud Boży; III. O hierarchicznym ustroju Kościoła, a w szczególności o episkopacie; IV. Katolicy świeccy; V. Powszechne powołanie do świętości w Kościele; VI. Zakonnicy; VII. Eschatologiczny charakter Kościoła pielgrzymującego i jego związek z Kościołem w niebie; VIII. Błogosławiona Dziewica Boża Rodzicielka w tajemnicy Chrystusa i Kościoła.

Z kolei konstytucja duszpasterska Gaudium et spes najpierw ukazuje sytuację człowieka w świecie współczesnym. Sobór przedstawia Kościól jako znak i gwarancję transcendentnego charakteru osoby:

Wyznając najszczytniejsze powołanie człowieka i głosząc, że ma w sobie zasiane pewne Boskie ziarno, ofiarowuje [Sobór] rodzajowi ludzkiemu szczerą współpracę Kościoła dla zaprowadzenia odpowiadającego temu powołaniu braterstwa wszystkich ${ }^{25}$.

\section{Eklezjologia posoborowa}

Po II Soborze Watykańskim jego doktryna o Kościele jako ludzie Bożym² interpretowana przez różnych autorów w odmiennych kontekstach kulturowych, doznała zniekształcenia, co doprowadziło do swoistego kryzysu jego tożsamości. Wynikało to nie tylko $\mathrm{z}$ bogactwa samych tekstów magisterialnych i przełomu, jaki wnosiły w praktyczną i profetyczną misję katolików, lecz ze sposobów

25 KDK 3.

26 Por. A. Luneau, M. Bobichon, Kościót ludem Bożym. Od owczarni do ludu Przymierza, Warszawa 1980, s. 163-312. 
wprowadzania soborowych reform. Odnowa nie przebiegała często w zgodzie $z$ literą i duchem Vaticanum II. Uwidoczniło się to najpierw w dowolności i nadużyciach przy wprowadzaniu zmian liturgicznych oraz sprzeciwem wobec takiego działania, czego przykładem był ruch fundamentalistyczny z abp. Marcelem Lefebvrem $(\dagger 1991)$ na czele ${ }^{27}$.

Trudności ze zrozumieniem soborowej eklezjologii pojawiły się też w zakresie jej misji i natury. Ulegając postulatom rewolucji obyczajowej 1968 r., wielu teologów Europy Zachodniej domagało się większej demokratyzacji Kościoła. Błędne rozumienie ludu Bożego - o mocnym zabarwieniu politycznym i socjologicznym - przybierało postać tzw. „Kościoła oddolnego”. Natomiast pojęcie „ludu Bożego” sobór wyraźnie ujmował w sposób historiozbawczy, akcentując jego wybór, powołanie i posłanie przez Trójjedynego Boga ${ }^{28}$. Takie rozumienie istotnie różni się od ujęcia „ludu” wypływającego z politycznej wizji Oświecenia, znajdującej się u podstaw współczesnych systemów demokratycznych. Z kolei w Ameryce Łacińskiej pojawiła się tzw. teologia wyzwolenia, która upolityczniła pojęcie „ludu Bożego”, przesadnie akcentując wymiar socjologiczny na niekorzyść teologicznego. Najbardziej wpływowym przedstawicielem tej teologii zostal Leonardo Boff ze swoją książką Kościót - charyzmat i wta$d z a$. Studia dotyczqce walczacej eklezjologi $i^{29}$. Proponowana wizja marksistowska ze zbrojną walką klas zdecydowanie jednak została odrzucona przez Kongregację Nauki Wiary w instrukcjach Libertatis nuntius (1984) oraz Libertatis conscientia (1986).

Wskazane czynniki (przełom soborowy, błędny ruch liturgiczny, demokratyzacja Kościołów Europy Zachodniej, latynoamerykańska teologia wyzwolenia) spowodowały nadzwyczajne zebranie Synodu Biskupów w 1985 r. ${ }^{30}$, podczas którego opowiedziano się za odejściem od kategorii ludu Bożego na rzecz rozumienia Kościoła jako communio. Chodzi bowiem o zjednoczenie wierzącego z Bogiem przez Jezusa Chrystusa w Duchu Świętym, co dokonuje się w słowie

${ }^{27}$ M. Lefebvre założył w 1969 r. we Fryburgu szwajcarskim Bractwo Piusa X. W 1970 r. powołał do życia seminarium duchowne w Écône (Szwajcaria), rozpoczynając wbrew zakazowi Rzymu regularnie święcić diakonów i kapłanów. Do definitywnej schizmy doszło w 1988 r. na skutek odrzucenia przez niego nauki soboru jako heretyckiej oraz wyświęcenia czterech biskupów. Lefebvre zmarł niepojednany z Kościołem katolickim. Bractwo założone przezeń znalazło zwolenników w różnych krajach. Niektórzy z nich powracają do jedności Kościoła rzymskokatolickiego.

28 Por. S. Jaśkiewicz, Eklezjologia ludu Bożego w nurcie II Soboru Watykańskiego, [w:] Kościót lokalny w Kościele Chrystusa, red. R. Kantor, Kraków 2015, s. 7-32.

29 Zob. Iglesia - Carisma y Poder. Ensayos de Ecclesiología Militante, Petrópolis 1981.

30 Zob. Nadzwyczajny Synod Biskupów, Dwudziestolecie Soboru Watykańskiego II. Kościót kierowany przez stowo Boże sprawuje tajemnice Chrystusa dla zbawienia świata, Wrocław 1986. 
Bożym i sakramentach. Chrzest jest bramą i fundamentem kościelnej wspólnoty, a Eucharystia jej źródłem i szczytem. Doprecyzowaniem rozumienia Kościoła jako communio był dokument Kongregacji Doktryny Wiary w 1992 r. pt. List do Biskupów Kościoła Katolickiego o niektórych aspektach Kościota pojętego jako komunia ${ }^{31}$.

Oprócz upolitycznienia kategorii ludu Bożego doszło też do niewłaściwych interpretacji w zakresie kolegialności biskupów i prymatu papieskiego. Chodziło o dowartościowanie życia kolegialnego w Kościołach partykularnych i lokalnych, a zwłaszcza w strukturach Kościoła powszechnego. W tym celu powołano do życia rzymski synod biskupów, który jednak w odniesieniu do papieża - głowy kolegium - posiadał głos doradczy. Dzisiaj instytucja synodów rozwinęła mocno swoją kolegialną działalność, angażując zarówno hierarchię, jak i świeckich. Działalność konferencji biskupich w poszczególnych regionach i krajach określił list apostolski motu proprio Jana Pawła II O naturze teologicznej i prawnej konferencji episkopatów z 1998 r. Owocem obrad każdorazowego synodu jest adhortacja, jak np. papieża Franciszka Evangelii gaudium na temat nowej ewangelizacji (2013), Amoris laetitia odnosząca się do małżeństwa i rodziny (2016) czy Gaudete et exsultate o powołaniu do świętości w świecie współczesnym (2018).

Życie Kościoła posoborowego naznaczyły również kolejne pontyfikaty: św. Jana XXIII (1958-1963), św. Pawła VI (1963-1978), św. Jana Pawła II (1978-2005), Benedykta XVI (2005-2013) oraz Franciszka. Nie wolno też pominąc milczeniem dokumentów o wielkiej wadze teologicznej: Kodeksu Prawa Kanonicznego i Katechizmu Kościota Katolickiego. Ukazując znaczną rolę papieży ostatnich dziesiątków lat, trzeba też przywołać zadziwiającą kontestację ich władzy prymacjalnej i niektórych elementów nauczania (np. H. Küng).

W posoborowy czas wpisują się też obchody Wielkiego Jubileuszu Chrześcijaństwa, jakie miały miejsce w 2000 r., do którego św. Jan Paweł II przygotowywał wiernych już listem apostolskim Tertio Millennio Adveniente (1994 r.) W tym dokumencie papież: zachęcał chrześcijan do nowego odkrycia obecności Ducha Świętego; opowiadał się za opcją Kościoła na rzecz ubogich i odepchniętych; upominał się o męczenników XX wieku oraz nawoływał do rachunku sumienia $z$ grzechów popełnionych przez chrześcijan w samym Kościele. Ważnym dokumentem była też deklaracja Kongregacji Nauki Wiary Dominus Iesus. O jedyności i porwszechności zbawczej Jezusa Chrystusa i Kościota z roku 2000. Uroczyste zamknięcia Jubileuszu przyniósł list apostolski Novo Millennio Ineunte z $2001 \mathrm{r}$.

31 Zob. Communio w chrześcijańskiej refleksji o Kościele, red. A. Czaja, M. Marczewski, Lublin 2004. 
Tematyka Kościoła - communio została pogłębiona w nauczaniu Jana Pawła II (encyklika Ecclesia de Eucharistia, 2003) oraz Benedykta XVI, którzy ukazywali Kościól jako wspólnotę eucharystyczną.

Jednym z osiągnięć aktualnej katolickiej nauki o Kościele jest też wypracowanie rozumienia jedności określanej jako rzeczywistość złożona bądź w pełni katolic$\mathrm{ka}^{32}$, a nawet „święta tajemnica jedności” ${ }^{33}$, co należy wiązać z rozwojem dialogu ekumenicznego i eklezjologii communio. Katolicka eklezjologia jedności konfrontuje się z analogiczną myślą Kościołów i Wspólnot niekatolickich ${ }^{34}$. Jej rozwój dokonuje się nade wszystko w ramach eklezjologii komunijnej, zainspirowanej orzeczeniami II Nadzwyczajnego Zgromadzenia Synodu Biskupów w 1985 r.

Podjęcie przez eklezjologię problematyki ekumenicznej (encyklika Ut unum sint Jana Pawła II, 1995 r.) wiąże się też dziś z zagadnieniami pluralizmu religijnego. Wskutek globalizacji wyznawcy innych religii pojawili się blisko każdego z nas.

Eklezjologia współczesna stoi też wobec nowych wyzwań, co wiąże się choćby z dramatycznym spadkiem liczby chrześcijan w Europie, a z potężnym wzrostem liczebnym w Afryce, Azji czy Ameryce Południowej.

${ }^{32}$ Por. KK 8, 13; DKW 25; DM 6, 22.

${ }^{33}$ DE 2.

${ }^{34}$ Por. A. Czaja, Eklezjologia jedności. Perspektywa rzymskokatolicka, „Roczniki teologii ekumenicznej" t. 2 (57) 2010, s. 5-20. 
4.4. Uniwersytet Papieski

Tf: Jana Pawta II 